\title{
Niemiecka chadecja wobec konfliktu rosyjsko-ukraińskiego
}

Trwający od 2014 r. konflikt rosyjsko-ukraiński okazał się być o wiele bardziej skomplikowany i długotrwały niż początkowo przypuszczano. Silnie uwidocznił rozbieżne stanowiska wobec Federacji Rosyjskiej państw członkowskich Unii Europejskiej. Mnogość opinii występująca na arenie europejskiej była odbiciem dyskusji toczonych w poszczególnych państwach członkowskich. Również na niemieckiej scenie politycznej nie było zgody co do reakcji na działania Kremla. Niniejszy artykuł ma na celu prześledzenie stanowisk polityków niemieckiej chadecji wobec konfliktu rosyjsko-ukraińskiego oraz wpływu, jaki wywarli na działania Unii Europejskiej i Rosji.

Wydarzenia na Ukrainie początkowo zdominowane zostały przez tematy związane z wynikami wrześniowych wyborów do Bundestagu, w których frakcja CDU/CSU po raz trzeci zdobyła największą ilość głosów, oraz z długotrwałymi negocjacjami pomiędzy chadecją i SPD dotyczącymi tworzenia nowego rządu . W listopadowym oświadczeniu rządu z okazji III szczytu Partnerstwa Wschodniego ${ }^{2}$ kanclerz Angela Merkel oznajmiła, że widzi „ogromny potencjał” w politycznym i gospodarczym zbliżeniu m.in. z Ukrainą. Przekonywała, iż zbliżenie z Unią Europejską i współpraca z Rosją nie wykluczają się wzajemnie, że nie jest to alternatywa z rodzaju ,albo Rosja albo Unia". Podczas dyskusji w Bundestagu przedstawiciele frakcji CDU/CSU podkreślali, iż Partnerstwo Wschodnie Unii Europejskiej nie jest skierowane przeciwko Rosji. Andreas Schockenhoff, zastępca przewodniczącego frakcji parlamentarnej CDU/CSU ds. zagranicznych, obrony i Europy, oświadczył, iż nie do przyjęcia jest, że Kreml wywiera presję gospodarczą na kraje europejskie, które starają się zbliżyć do UE. Zaznaczał, iż ze wspólnej przestrzeni gospodarczej mogłaby skorzystać również Federacja Rosyjska. Natomiast przewodniczący frakcji parlamentarnej CDU/CSU - Volker Kauder - przekonywał, że polityka zimnej wojny musi zostać przezwyciężona oraz wezwał Rosję do współpracy z UE i krajami Europy Wschodniej (Der Kalte, 2013).

Po przerwaniu przez stronę ukraińską rozmów dotyczących podpisania umowy stowarzyszeniowej z Unią podczas listopadowego szczytu w Wilnie rząd RFN, w pełni popierany przez frakcję CDU/CSU, oświadczył, iż decyzja ta nie zamyka Ukrainie drogi do partnerstwa. Postanowiono poczekać na jej zmianę. Rzecznik ds. polityki zagra-

\footnotetext{
1 Umowa koalicyjna podpisana została 16 grudnia, dzień później Angela Merkel została ponownie wybrana na kanclerza RFN.

2 Partnerstwo Wschodnie zakłada zacieśnienie wspólpracy z Białorusią, Ukraina, Mołdawią, Gruzją, Azerbejdżanem i Armenią. Podczas szczytu miała zostać podpisana umowa o stowarzyszeniu i wolnym handlu z Ukraina, o ile Kijów spełni stawiane mu warunki (np. dotyczące zagwarantowania wolnych i uczciwych wyborów, nieprzekupności organów sądowych i wprowadzenia w życie obiecanych reform).
} 
nicznej frakcji CDU/CSU, Philipp Mißfelder, przekonywał, iż rozmowy muszą być prowadzone, gdyż nie ma innej alternatywy. Dodawał przy tym, iż stabilizacja, rozwój gospodarczy oraz demokratyzacja leżą w interesie zarówno europejskiej, jak i niemieckiej polityki zagranicznej. Według polityka należało silnie podkreślać, że Partnerstwo Wschodnie można powiązać z preferowaną przez Rosję wspólną przestrzenią gospodarczą rozciaggającą się od Lizbony do Władywostoku (Weiterhin, 2013).

Ani w Berlinie, ani w Brukseli nie przewidywano, że odmowa podpisania umowy wywoła masowy protest obywateli Ukrainy. CDU/CSU wyrażało solidarność z pokojową opozycją na Ukrainie. A. Schockenhoff oświadczył, iż frakcja jest głęboko zaniepokojona pogarszaniem sytuacji przez rząd w Kijowie oraz stanowczo potępia przemoc ukraińskich służb bezpieczeństwa wobec demonstrantów (CDU/CSU, 2013). Kilka dni później komentując postawę rosyjskiego ministra spraw zagranicznych - Siergieja Ławrowa - podczas grudniowego spotkania $z$ Wysokim przedstawicielem UE ds. zagranicznych - Catherine Ashton - polityk wyraził opinię, iż Rosja „będzie wywierać na Ukrainę i inne kraje Partnerstwa Wschodniego, jak Mołdawia, ogromną presję dopóki chcą podążać inną drogą niż Moskwa. Jest to nie do przyjęcia". W związku z postawą Kremla Schockenhoff podkreślał, iż po pierwsze, potrzebny jest realistyczny dialog z Moskwą. Po drugie, zasady paryskiej karty OBWE muszą być przestrzegane. Każdy kraj musi samodzielnie decydować, bez jakichkolwiek nacisków politycznych i gospodarczych, czy chce silniej związać się z UE, czy nie. Po trzecie, ogromny nacisk na Ukrainę ze strony Moskwy jasno dowodzi, że rząd Janukowycza nie rozwija kraju i regionu, ale prowadzi je do rosnącej niestabilności. Po czwarte, w interesie UE leży nadanie Ukrainie jasnej europejskiej orientacji i zakotwiczenia. Mogą one znacznie wykraczać poza układ o stowarzyszeniu w kierunku członkostwa w Europejskim Obszarze Gospodarczym lub w Unii, jeśli Ukraina tego zechce i stworzy odpowiednie warunki (Strategisches, 2013). Stanowisko przedstawione przez zastępcę przewodniczącego frakcji po części pokrywało się z poglądami ministra spraw zagranicznych - Franka-Waltera Steinmeiera. Polityk SPD krytykował Rosję za wywieranie nacisku na Ukrainę, lecz również zakwestionował politykę Unii wobec Rosji, a dokładnie zignorowanie silnej zależności Kijowa od Kremla (Rede von Außenminister, 2013).

W związku z zaostrzaniem się sytuacji na Majdanie frakcja CDU/CSU wezwała rząd i opozycję do zaprzestania przemocy i powrotu do dialogu (Ausschreitungen, 2014). Podkreślano przy tym, iż również Moskwa powinna wykorzystać swoje wpływy u prezydenta Ukrainy Wiktora Janukowycza by powstrzymał przemoc (Regierung, 2014). Podobne sformułowania znalazły się w oświadczeniu rządowym. Angela Merkel przekonywała, że niemieccy politycy wspierają i kontynuują wysiłki w celu znalezienia pokojowego rozwiązania konfliktu ,wszystkimi dostępnymi środkami”. Skonstatowała, iż rząd federalny będzie rozmawiał z Rosją ku korzyści wszystkich w regionie (Freiheit, 2014). Wypowiedzi kanclerz oraz polityków frakcji CDU/CSU potwierdzały, iż RFN zamierza pełnić swoją tradycyjną rolę łącznika w utrzymywaniu dialogu między Moskwą i Brukselą, która wynikała zarówno z postrzegania pozycji państwa niemieckiego w polityce międzynarodowej, jak i chęci utrzymania dobrych relacji politycznych i gospodarczych z Rosją. Wiązały się również z przekonaniem, iż długotrwałe rozwiązanie kryzysu możliwe jest wyłącznie z zaangażowaniem Rosji i przy uwzględnieniu jej stanowiska. W tym kontekście należy również rozpatrywać słowa Kar- 
la-Georga Wellmanna, przewodniczącego Niemiecko-Ukraińskiej Grupy Parlamentarnej, który podczas odbywającej się pod koniec stycznia 2014 r. debaty w Bundestagu przekonywal, że ,jeśli będziemy rozwiązywać problem z Ukrainą w konflikcie z Rosją - my przeciwko Rosji czy Rosja przeciwko nam - będzie to politycznie i finansowo bardzo kosztowne" (Politischen, 2014). Wielokrotne rozmowy telefonicznie kanclerz z rosyjskim prezydentem nie przyniosły jednakże oczekiwanych rezultatów (Nur, 2014).

Frakcja jednoznacznie odrzucała zarzuty formułowane przez Kreml, że ingerencja Zachodu doprowadziła do eskalacji konfliktu. Z ust A. Schockenhoffa można było nawet usłyszeć odpowiedź, iż to Moskwa ponosi odpowiedzialność za ten konflikt, gdyż wywołała protesty, wiążąc podpisanie umowy o stowarzyszeniu z gospodarczymi sankcjami wobec Ukrainy (Sanktion, 2014). Bardziej stonowanie wypowiadał się K.-G. Wellmann, który przekonywał, iż jeśli Rosja chce być częścią Europy musi wziąć na siebie odpowiedzialność i przedyskutować przy stole negocjacyjnym konstruktywne pomysły jak postępować z Ukrainą. Polityk był przekonany, iż konflikt nie sprzyja również Rosji, gdyż pozostawi po sobie podzielony kraj bez struktur politycznych (Das Ziel, 2014). Natomiast dr Norbert Röttgen, Przewodniczący Komisji Spraw Zagranicznych w Bundestagu, nawoływał W. Janukowycza oraz ukraiński parlament do przeprowadzenia wyborów prezydenckich i parlamentarnych $(E s, 2014)$. W podobnym tonie wypowiadał się zastępca przewodniczącego frakcji CDU/CSU - Arnold Vaatz. Jednocześnie polityk podkreślał, iż Unia musi zacząć aktywnie działać nakładając sankcje na Ukraińców szkodzących państwu (Gewalt, 2014).

21 lutego Wiktor Janukowycz, trzej liderzy ukraińskiej opozycji - Witalij Kliczko, Arsenij Jaceniuk i Ołeh Tiahnybok - ministrowie spraw zagranicznych Niemiec i Polski - F.-W. Steinmeier i Radosław Sikorski - oraz przedstawiciel Rosji - Władimir Łukin - uzgodnili porozumienie, na mocy którego miały odbyć się wcześniejsze wybory prezydenckie, powstać rząd jedności narodowej i nastąpić powrót do konstytucji z 2004 r. Po ucieczce Janukowycza z Kijowa i podjęciu uchwały przez Radę Najwyższą o odsunięciu prezydenta od władzy zastępczyni przewodniczącego frakcji, Sabine Weiss, i rzeczniczka ds. rozwojowo-politycznych frakcji parlamentarnej CDU/CSU, Sibylle Pfeiffer, przekonywały, iż powinno szybko dojść do utworzenia rządu tymczasowego, który ustabilizuje sytuację w kraju. Postulowały również, iż społeczność międzynarodowa, w tym także Rosja, musi zrobić wszystko by nastąpił pokojowy proces wyboru prezydenta i parlamentu Ukrainy. Ponadto pozytywnie odniosły się do możliwości udzielenia pomocy finansowej Ukrainie przez UE i Międzynarodowy Fundusz Walutowy - MFW (Weg, 2014). Kilka dni później Ołeksandr Turczynow wybrany został na stanowisko pełniącego obowiązki prezydenta, a Arseni Jazenjuk na premiera Ukrainy. Przemawiając w imieniu frakcji CDU/CSU A. Schockenhoff oświadczył, iż dzięki temu Ukraina zyskała możliwość pokojowego, demokratycznego i konstytucyjnego rozwoju. Zgodnie z polityką rządu oraz frakcji podkreślał, iż przy konsolidacji i stabilizacji Ukrainy, Rosja jest ważnym czynnikiem oraz wyraził nadzieję, iż się do nich przyczyni. Wspomniał również, iż chadecja będzie wspierać proeuropejską politykę Ukrainy oraz zdecydowanie opowiadać się za tym, by Unia udzieliła jej wsparcia w rozwoju (Chance, 2014).

W odpowiedzi na wyniki wyborów obradujący przy drzwiach zamkniętych parlament krymski wybrał nowy rząd oraz podjął decyzję o zorganizowaniu referendum 
w sprawie przyszlego statusu regionu. Następnie Siergiej Aksionow - premier Republiki Autonomicznej Krymu - zwrócił się z oficjalną prośbą do prezydenta Władimira Putina o zapewnienie spokoju i bezpieczeństwa mieszkańcom półwyspu. Polityk poinformował także, że władze autonomii przejmują całkowitą kontrolę m.in. nad siłami milicyjnymi i strażą graniczną znajdującą się na tym terenie (Ukraina, 2014). Po podjęciu decyzji przez parlament krymski o odłączeniu się od Ukrainy oraz wkroczeniu wojsk rosyjskich na Krym kanclerz A. Merkel zaproponowała utworzenie tzw. grupy kontaktowej, która miała umożliwić rosyjsko-ukraińskie rozmowy przy mediacji międzynarodowych partnerów. Przychylność rosyjskiego prezydenta wobec tej inicjatywy Philipp Mißfelder odczytał jako realną możliwość znalezienia dyplomatycznego rozwiązania. Podkreślał przy tym, iż gdyby dyplomacja zawiodła istnieją pewne możliwości zwiększenia presji na Rosje, jak np. usunięcie tego państwa z G-8, które miałoby dla niego ogromne konsekwencje ekonomiczne. Rzecznik frakcji CDU/CSU ds. polityki zagranicznej określił jako nieprawdę pogląd, że Putin tylko czekał na okazję, żeby wkroczyć na Krym. Według Mißfeldera Moskwa zareagowała w sposób eskalujący sytuację na porozumienia zawarte 21 lutego (Ukraine, 2014).

Na początku marca unijni ministrowie spraw zagranicznych odbyli nadzwyczajne posiedzenie poświęcone sytuacji na Ukrainie. Rada ds. zagranicznych „zgodziła się szybko pracować nad przyjęciem ograniczeń dotyczących zamrażania i odzyskiwania majątku osób zidentyfikowanych jako odpowiedzialne za sprzeniewierzenie funduszy państwowych i zamrożeniem aktywów osób odpowiedzialnych za łamanie praw człowieka" (Council 1, 2014). 3 dni później odbyło się nadzwyczajne posiedzenie szefów państw i rządów odnośnie Ukrainy. W wydanym oświadczeniu potępiono „niesprowokowane pogwałcenie przez Federację Rosyjską suwerenności i integralności terytorialnej Ukrainy" i wezwano Moskwę do ,natychmiastowego wycofania swoich sił zbrojnych do miejsc ich stałego stacjonowania zgodnie ze stosownymi porozumieniami" oraz do „umożliwienia międzynarodowym obserwatorom natychmiastowego dostępu”. Podkreślono, iż rozwiązanie kryzysu na Ukrainie musi opierać się na integralności terytorialnej, suwerenności i niezależności Ukrainy oraz na ścisłym przestrzeganiu międzynarodowych standardów. Decyzję Rady Najwyższej Autonomicznej Republiki Krymu o przeprowadzeniu referendum w sprawie przyszłego statusu tego terytorium uznano za nielegalną jako sprzeczną z ukraińską konstytucją. Postanowiono zawiesić rozmowy dwustronne $z$ Rosją w kwestiach wizowych, a także rozmowy na temat nowej umowy o partnerstwie i współpracy. Według szefów państw i rządów rozwiązania kryzysu należało poszukiwać na drodze negocjacji między rządami Ukrainy i Federacji Rosyjskiej, w tym poprzez ewentualne mechanizmy międzynarodowe. Unia zagroziła, iż w przypadku braku rezultatów wprowadzi dodatkowe sankcje gospodarcze i indywidualne, jak zakaz podróżowania i zamrożenie aktywów, oraz odwoła szczyt UE-Rosja (Rada Europejska, Oświadczenie, 2014).

Ustalenia te zostały pozytywnie przyjęte przez frakcję CDU/CSU. Andreas Schockenhoff określił je wręcz jako niezbędne. Moskwa, według polityka, musiała podjąć wszelkie kroki, aby deeskalować sytuację, m.in. zatwierdzić utworzenie grupy kontaktowej i odwrót rosyjskich sił zbrojnych nielegalnie przebywających na Krymie, pozwolić obserwatorom OBWE, aby wykonywali swoją pracę na tym terenie, wyraźnie odrzucić ideę secesji ukraińskiego półwyspu oraz prowadzić bezpośrednie rozmowy 
z nowo wybranym rządem Ukrainy. Schockenhoff po raz kolejny podkreślał, iż chadecja opowiada się za szybkim podpisaniem umowy stowarzyszeniowej, pod warunkiem, iż nie wpłynie to negatywnie na ukraiński eksport do Rosji (EU-Assoziierungsabkommen, 2014). Natomiast Volker Kauder w wydanym oświadczeniu obiecywał, iż Niemcy będą „działać rozważnie”, aby znalezione zostało dobre rozwiązanie sytuacji na Krymie. Polityk wspomniał również o 11 miliardowej finansowej pomocy Unii Europejskiej, którą określił jako prawdziwy i pozytywny sygnał. Ponadto, według Kaudera, ważne było, by państwa Unii Europejskiej ,nie dały się podzielić tym kryzysem. Tylko w ten sposób możemy osiagnąć, że rosyjska polityka mocy także w przyszłości zattzyma się przed granicami UE" (Politische, 2014).

Ze względu na nieudane próby zmiany stanowiska Rosji ton wypowiedzi A. Merkel się zaostrzył. W oświadczeniu rządu z 13 marca kanclerz skrytykowała politykę Kremla wobec Kijowa oświadczając, iż „działania Rosji na Ukrainie wyraźnie stanowią naruszenie podstawowych zasad prawa międzynarodowego. [...] Terytorialna integralność Ukrainy nie jest kwestią negocjacji". Polityk zaznaczyła, że jeśli Rosja nie powróci na ścieżkę współpracy i prawa międzynarodowego, UE jest gotowa i zdecydowana wprowadzić sankcje gospodarcze. Kanclerz podkreślała jednakże, że „działania militarne nie są rozwiązaniem". Opowiedziała się za takimi polityczno-dyplomatycznymi krokami, jak działanie w ramach grupy kontaktowej i komisji obserwatorów OBWE, ułatwienia przy otrzymywaniu wiz oraz podpisanie umowy stowarzyszeniowej (Regierungserklärung von Bundeskanzlerin, 2014; Dreiklang, 2014; Die territoriale, 2014).

Przemówienie kanclerz spotkało się z życzliwym przyjęciem ze strony chadeków. Gerda Hasselfeldt, zastępczyni przewodniczącego frakcji parlamentarnej CDU/CSU, koncyliacyjnie oświadczyła, iż osiagnięcie trwałego pokoju możliwe jest we współpracy z Rosja, dlatego należy ukierunkować to państwo na „,prawdziwe negocjacje”. Podkreślała, iż celem międzynarodowej grupy kontaktowej musi być budowa i przywrócenie zaufania, ale przede wszystkim zapewnienie integralności terytorialnej i suwerenności Ukrainy oraz praw człowieka i praw mniejszości (Friedliches, 2014). Karl-Georg Wellmann przestrzegał przed aneksją Krymu mówiąc, iż Rosja straci o wiele więcej ekonomicznie niż Zachód. Nawoływał, by zastanowić się nad dalszymi krokami, jeśli obywatele Krymu zadecydują w referendum o przyłączeniu do Rosji. „Musimy zachować zimną krew. [...] Musimy też pamiętać, że w pewnym momencie znów mamy uprawiać politykę i nie możemy zamykać każdych drzwi" (Russland muss, 2014). $\mathrm{Z}$ kolei Andreas Schockenhoff podniósł temat usunięcia broni jądrowej z terenu Ukrainy. Uznał, iż rosyjskie gwarancje bezpieczeństwa, które Moskwa zapewniła Ukrainie podpisując Traktat Budapesztański, istnieją tylko na papierze i nie są nic warte w rzeczywistości. Podkreślał, że jeśli zostanie dokonana secesja Krymu i zostanie on włączony do Rosji, będzie to oznaczać, iż dla Moskwy prawo międzynarodowe jest przestarzałe, będzie naginane i łamane. Według zastępcy przewodniczącego frakcji parlamentarnej CDU/CSU ds. zagranicznych, obrony i Europy takie zachowanie Moskwy jest poważnym wykroczeniem wobec obowiązków stałego członka Narodów Zjednoczonych, światowego pokoju i bezpieczeństwa międzynarodowego. Jest ono również całkowicie sprzeczne z obowiązkami członków OBWE, którzy promują bezpieczeństwo i współpracę w Europie. Polityk wciąż jednak uznawał, że uniknięcie eskalacji konfliktu jest możliwe (Wir wollen, 2014). 
16 marca odbyło się referendum, w którym 96,77\% głosujących opowiedziało się za zjednoczeniem Krymu z Rosją. Krótko potem Rada Najwyższa Krymu przyjęła uchwałę o niepodległości Krymu. Jeszcze tego samego dnia W. Putin podpisał dekret o uznaniu Krymu suwerennym i niepodległym państwem, a następnie Traktat o włączeniu Republiki Krymu i Sewastopola do Rosji (Blyskawiczne, 2014). Kanclerz ostro skrytykowała przeprowadzenie referendum mówiąc, iż było ono niezgodne z konstytucją Ukrainy i normami prawa międzynarodowego. Powtórzyła, że Niemcy, Unia Europejska i MFW będą wspierać Ukrainę pomocą, w tym finansową (Merkel, 2014). Podobne wypowiedzi można było usłyszeć z ust unijnych ministrów spraw zagranicznych w Brukseli. Politycy postanowili zastosować dodatkowe środki przeciwko 21 urzędnikom odpowiedzialnym za działania zagrażające integralności terytorialnej Ukrainy (Council 2, 2014). Podczas spotkania F.-W. Steinmeier promował ideę wysłania na Ukrainę misji OBWE, której zadaniem miało być ustalenie faktów i obserwowanie, czy Rosja jest aktywna poza Krymem i nadal destabilizuje Ukrainę. W opinii ministra miało to pomóc w powstrzymaniu eskalacji konfliktu (Kalendarium 1, 2014).

Kilka dni później prezydent Władimir Putin podpisał akty ratyfikacyjne traktatu o przyjęciu Republiki Krymu do Federacji Rosyjskiej. Działanie to zostało natychmiast skomentowane przez członków chadecji. Nawiązując do grudniowej wypowiedzi Steinmeiera przewodniczący brandenburskiej grupy posłów CDU/CSU - Michael Stübgen - winą za „dyplomatyczną katastrofę", czyli fiasko rozmów między Brukselą, Kijowem i Moskwą, obarczył nie tylko Rosję, ale również Unię. W ocenie tego posła UE wyraźnie nie doceniła geopolitycznej kwestii Ukrainy dla Rosji i podstawowych wewnętrznych konfliktów politycznych na Ukrainie, których nie można usunąć poprzez zbliżenie z UE. Polityk, podobnie jak reszta chadeckich posłów, poparł finansową pomoc dla Ukrainy i możliwość podpisania umowy stowarzyszeniowej przez to państwo, a także krytykowaną przez Unię ,popierającą sankcje, ale wstrzemięźliwą i nieagitująca" postawę rządu federalnego (Russland bestimmt, 2014). Niedługo potem (21 marca) podpisana została pierwsza polityczna część umowy stowarzyszeniowej, w której nie znalazł się zapis dotyczący przystąpienia Ukrainy do Unii (Uklad, 2014).

W następnych tygodniach rząd federalny zaczął przywiązywać jeszcze większą uwagę do takiej modyfikacji unijnej polityki sąsiedztwa, by integracja gospodarcza z UE nie wykluczała rozwijania współpracy państw Partnerstwa Wschodniego z Moskwa. Ta jednak zupełnie zignorowała te wysiłki i nie zmieniła swej postawy względem Ukrainy. Wobec tego niemiecka kanclerz po raz kolejny skrytykowała działania Kremla. Podczas debaty budżetowej Merkel oświadczyła, iż „niestety, na wielu odcinkach nie widać, by Rosja przykładała się do deeskalacji sytuacji" i po raz kolejny wezwała Putina do podjęcia dialogu z nowymi władzami w Kijowie (Rede von Bundeskanzlerin Dr, 2014). Według A. Schockenhoffa brak konkretnych działań strony rosyjskiej świadczył o tym, iż nie była ona zainteresowana stabilizacją Ukrainy, co jednocześnie stawiało pod znakiem zapytania uczciwość jej propozycji w ramach grupy kontaktowej. Polityk twierdził wręcz, iż Rosja zrobi wszystko by zniszczyć unijne starania. Prognozował, iż państwo to będzie wykorzystywać rozczarowanie społeczeństwa ukraińskiego i utratę odporności przez unijnych partnerów by podzielić kraj. Jednocześnie zaznaczał, iż Unia nadal zainteresowana jest ścisłą wspólpracą z silną, politycznie i gospodarczo nowoczesna, konstytucyjną i demokratycznie działającą Rosją. Kooperacja 
z Moskwą, według Schockenhoffa, musi pozostać naczelnym elementem unijnej polityki, należy jednak uważać by nie podzieliła ona państw członkowskich (Realistische, 2014).

Wraz z narastaniem konfliktu od Niemców zaczęto oczekiwać w polityce zagranicznej bardziej widocznego przewodnictwa. W opublikowanym pod koniec kwietnia raporcie przewodniczących CDU/CSU oraz SPD można było przeczytać, iż Republika Federalna nie ucieka od międzynarodowej odpowiedzialności i jest gotowa do spełnienia oczekiwań dotyczących pokojowego rozwiązywania kryzysów i konfliktów przy pomocy środków dyplomatycznych i współpracy na rzecz rozwoju. Postulowali by Rosja podążała ścieżką dyplomatycznych rozwiązań, usunęła swoje wojska z regionu przygranicznego, a tym samym przyczyniła się do widocznego złagodzenia sytuacji w tym regionie. Ponadto koalicjanci domagali się by przyjęta za zgodą Rosji misja OBWE na Ukrainie została rozbudowana i działała bez przeszkód, w celu uzyskania wiarygodnych informacji. Ponieważ Rosja „swoją epatującą zagrożeniem retoryką i manewrami wojskowymi na granicy z Ukrainą powoduje dalszą eskalację konfliktu", wsparli determinację Unii Europejskiej, by za pomocą stopniowych sankcji powstrzymać te działania. Wyrazili również wsparcie dla rządu federalnego, który stał na stanowisku, iż w tej napiętej sytuacji wymagane jest przemyślane działanie i wykluczał rozwiązania militarne. Podkreślali, iż kraje Partnerstwa Wschodniego nie powinny być zmuszane do wyboru między zbliżeniem z UE lub wszechstronną współpracą z Rosją. Według polityków współpraca z Unią w ramach Partnerstwa nie była wymierzona przeciwko Rosji. Ponadto poparli ukraiński rząd i parlament, które sprzeciwiały się decentralizacji oraz odrzuciły rosyjską propozycję federalizacji kraju jako zagrażające integralności terytorialnej Ukrainy (Beschluss, 2014).

W trakcie majowej debaty w Bundestagu odnośnie sytuacji na Ukrainie parlamentarzyści CDU/CSU zwracali uwagę na kilka aspektów. Przewodniczący Komitetu ds. Unii Europejskiej w Bundestagu, Gunther Krichbaum, ostrzegał, że od starć między Ukraińcami i prorosyjskimi separatystami może wybuchnąć „ogien”” w sąsiednich państwach, takich jak Mołdawia. Przewodniczący niemiecko-ukraińskiej grupy parlamentarnej, Karl-Georg Wellmann, mówił natomiast o asymetrycznej wojnie sprowokowanej przez rosyjskie siły specjalne. Biorąc pod uwagę dramatyczne wydarzenia rozgrywające się na Ukrainie minister spraw zagranicznych po raz kolejny wykluczył rozwiązania militarne. F.-W. Steinmeier tłumaczył, że dyplomacja zawsze posuwa się tylko małymi krokami, ale „rezygnacja nie jest opcja”. Wezwał do kolejnej konferencji genewskiej z udziałem Rosji, Ukrainy, UE i USA celem uzgodnienia wiążących kroków w kierunku deeskalacji ${ }^{3}$. Również posel CSU - Florian Hahn - podkreślał, że trzeba „wyczerpać wszystkie środki dyplomatyczne”. Wśród mówców znaleźli się również tacy, którzy opowiadali się za kolejnymi sankcjami wobec Rosji, jeśli moskiewski rząd nie zrealizuje kwietniowych ustaleń (np. G. Kirchbaum). W tym kontekście minister ds. obrony narodowej Ursula von der Leyen oświadczyła, iż „nie pozwolimy by architektura bezpieczeństwa w Europie, którą pracowicie budowano w ciągu ostat-

3 Podczas kwietniowych rozmów genewskich minister spraw zagranicznych Ukrainy, Rosji, USA i Wysoki Przedstawiciel UE zgodzili się na zaprzestanie przemocy, rozbrojenie nielegalnych grup, ewakuację budynków oraz zaniechanie karania. 
nich kilku dekad, została rozdarta i podeptana w ciagu kilku tygodni" (Sorge, 2014). Wielokrotne rozmowy telefoniczne Merkel z Putinem oraz ciagge podróżowanie ministra spraw zagranicznych, celem osiagnięcia dyplomatycznego rozwiązania, nie przyniosły jednak oczekiwanych skutków (Russlands Vorgehen, 2014).

Po pojawieniu się doniesień o chęci zorganizowania referendum secesyjnego we wschodniej Ukrainie Andreas Schockenhoff domagał się by rząd w Moskwie wyraźnie zdystansował się od separatystów oraz przestał ich wspierać poprzez działania i wywiad rosyjskich sił specjalnych. Ponadto, według polityka, Rosja musiała wreszcie zacząc spełniać swoje zobowiązania wynikające z umowy genewskiej i wymagać od separatystów złożenia broni oraz opuszczenia nielegalnie zajmowanych budynków, ulic i placów. Dla zastępcy przewodniczącego frakcji parlamentarnej CDU/CSU ds. zagranicznych, obrony i Europy ważne było również, by Moskwa wsparła demokratyczne przemiany na Ukrainie - w szczególności wybory prezydenckie zaplanowane na 25 maja (Moskau, 2014). Proklamowanie Donieckiej i Ługańskiej Republiki Ludowej A. Schockenhoff określił jako nielegalne i naruszające wszelkie demokratyczne standardy. Ostro skrytykował Moskwę za ,respektowanie” wyników majowego referendum. W jego mniemaniu decyzja ta pokazywała, iż Kremlowi nie zależało na stabilizacji i odprężeniu sytuacji we wschodniej części Ukrainy (Referendum, 2014; Russland destabilisiert, 2014).

Po wyborach prezydenckich na Ukrainie, które wygrał Petro Poroszenko, grupa parlamentarna CDU/CSU wezwała rząd rosyjski by nie tylko uszanował ich obiektywną ocenę przez OBWE, ale także uznał ich wynik. Akceptację powiązano z natychmiastowym wycofaniem rosyjskich sił specjalnych i wywiadu ze wschodniej Ukrainy oraz z zaprzestaniem wspierania separatystów (Poroschenko, 2014). Chadecy zdecydowanie poparli także szefów państw i rządów, którzy zaapelowali do Moskwy o ,użycie jej wpływu na uzbrojonych separatystów celem deeskalacji sytuacji we wschodniej Ukrainie i uniemożliwienia dotarania separatystów i broni na Ukrainę". Schockenhoff podkreślał, że jeśli żołnierze rosyjscy i inni wyposażeni w najnowocześniejszą broń i myśliwce rosyjskie przedostaną się za zgodą rosyjskich wojsk granicznych i Moskwy do Ukrainy, będzie to forma rosyjskiej interwencji wojskowej na Ukrainie (Frieden, Sicherheit, 2014).

Przedstawiając oświadczenie rządu dotyczące spotkania grupy G-7 kanclerz Merkel oznajmiła, że polityczne i gospodarcze wspieranie Ukrainy to ważny punkt polityki triadycznej. Drugim był nieustanny wysiłek znalezienia dyplomatycznego rozwiązania kryzysu w dialogu i zmiana kursu Kremla z konfrontacyjnego na kooperacyjny. Polityk zauważyła jednak, iż rozmowy nie zawsze przynoszą oczekiwane skutki - Moskwa sygnalizowała np., iż będzie respektowała wyniki wyborów, rolę OBWE oraz wycofa część wojsk rosyjskich z granicy z Ukraina, ale nie zmieniła postawy wobec aneksji Krymu. Trzecim punktem owej polityki było wprowadzanie sankcji zatwierdzonych przez Unię. Kanclerz podkreślała, iż nie były one celem samym w sobie i nikt ich sobie nie życzył, ale są i będą wdrażane, jeśli Moskwa nie zmieni swojego sposobu działania (Frieden, Freiheit, 2014; Gruppe, 2014). Oświadczenie wywołało mieszane reakcje, również w szeregach frakcji CDU/CSU. Polityki triadycznej broniła m.in. Elisabeth Motschmann, członkini zarządu CDU-Niemcy (Russland wurde, 2014).

W związku z brakiem zmian w działaniu Kremla Unia Europejska wprowadziła obowiązujący od 25 czerwca zakaz importu towarów z Krymu i Sewastopola. Następ- 
nie podpisana została druga część umowy stowarzyszeniowej z Ukrainą, dotycząca utworzenia strefy wolnego handlu, współpracy w dziedzinie gospodarki oraz wymiaru sprawiedliwości i spraw wewnętrznych (Unijne, 2015).

Kilka dni później w Berlinie odbyły się rozmowy dotyczące utworzenia grupy kontaktowej ds. Ukrainy, w których udział brali szefowie MSZ Rosji, Ukrainy, Francji i Niemiec. Grupa, w której znajdowali się przedstawiciele rządu w Kijowie, ugrupowań separatystycznych, Rosji i OBWE, pierwszy raz zebrała się pod koniec lipca, lecz odbyte rozmowy nie przyniosły oczekiwanych rezultatów. Jednym z podawanych powodów było zatwierdzenie przez Radę Europejską 16 lipca kolejnych sankcji - objęcia 11 nowych osób zakazem podróżowania i zamrożenia ich aktywów w obrębie Unii (za działania podważające integralność terytorialną, suwerenność i niepodległość Ukrainy), a także zawieszenia porozumienia z 20 lutego w sprawie zezwoleń na eksport (Rada Europejska, Specjalne, 2014). Następnie wprowadzony został 3 pakiet sankcji obejmujący wybrane sektory rosyjskiej gospodarki oraz listę przedsiębiorstw i osób powiązanych z rosyjską elitą rządzącą (Unijne, 2015; Sus, 2014). Frakcja CDU/CSU z zadowoleniem przyjęła decyzje podjęte na szczycie (Fraktion, 2014).

Unijne sankcje, choć o ograniczonym zasięgu, mogły w dłuższej perspektywie pogorszyć sytuację makroekonomiczną Rosji i wpłynąć negatywnie na jej wizerunek na arenie międzynarodowej. W odpowiedzi na nie rosyjski rząd wprowadził roczny zakaz lub ograniczenie importu wybranych grup towarów i surowców rolno-spożywczych z krajów, które je nałożyły, ale również zgodził się, by w połowie sierpnia odbyły się rozmowy między ministrami spraw zagranicznych Rosji i Ukrainy w Berlinie. Spotkanie to Philipp Mißfelder ocenił jako ważny sygnał ponownego podjęcia dyskusji na poziomie politycznym. Rzecznik skonstatował, iż „nowa nić rozmów nie może zostać zerwana" (Gespräche, 2014). Kilka dni później podczas wizyty w Mińsku Putin poparł plan pokojowy prezydenta Poroszenki. Wydawać się zatem mogło, że rozmowy na linii Kijów-Moskwa przyniosły pozytywne zmiany. Nadzieje okazały się płonne, bowiem pod koniec miesiąca regularne oddziały rosyjskiej armii zajęły częśc kontrolowanych przez ukraińskie siły obwodów donieckiego i Ługańskiego (Sus, 2014). Według polityków niemieckiej chadecji, interwencja wojskowa oznaczała kpinę ze wszystkich wysiłków dyplomatycznych dotyczących deeskalacji sytuacji na Ukrainie i ,ogromne oszustwo światowej opinii publicznej”. Potępili rosyjską politykę i działanie, które określili jako „powtórzone i celowe naruszenie integralności terytorialnej oraz suwerenności Ukrainy". Ponadto wezwali rząd rosyjski do natychmiastowego zaprzestania interwencji, a państwa unijne do wzmocnienia i rozszerzenia sankcji (Kriegerischer, 2014). Schockenhoff po raz kolejny podkreślał jednak, że ,nie będzie militarnego rozwiązania kryzysu na Ukrainie, tylko polityczne" (Russland hat, 2014). Stanowisko to podzielał rzecznik ds. polityki zagranicznej frakcji CDU/CSU. Mißfelder przekonywał, iż moderowane przez OBWE negocjacje w Mińsku w sprawie zawieszenia broni spowodują, że granica między Rosją i wschodnią Ukrainąznów będzie bezpieczna (Die NATO, 2014).

W związku z przedłużającą się obecnością i działaniami rosyjskich wojsk na terytorium Ukrainy, Rada Europejska zaapelowała pod koniec sierpnia o przygotowanie nowych sankcji gospodarczych wobec Rosji. Zostały one jednogłośnie przyjęte przez państwa członkowskie UE w połowie następnego miesiąca (Unijne, 2015). Rosnący nacisk wywierany na obie strony konfliktu doprowadził wkrótce do spotkania grupy 
kontaktowej w Mińsku. Podczas niego podpisane zostało memorandum przewidujące wycofanie się każdej ze stron konfliktu na wschodniej Ukrainie oraz utworzenie strefy zdemilitaryzowanej między separatystami i siłami rządowymi. Ponadto porozumienie zakładało zawieszenie broni oraz zakaz podejmowania jakichkolwiek działań ofensywnych przez obie strony (Sus, 2014).

Starając się zaradzić pogarszającej się sytuacji ekonomicznej Ukrainy rząd RFN obiecał temu państwu kredyty w wysokości $500 \mathrm{mln}$ euro (Deutschland stellt, 2014). Kanclerz Merkel skłaniała się ponadto do odroczenia stosowania umowy o pogłębionej strefie wolnego handlu (DCFTA) ze względu na groźby Rosji, że wprowadzi cła importowe na towary ukraińskie od 1 listopada, jeśli jej uwagi do umowy o stowarzyszeniu Ukrainy z Unią nie zostaną uwzględnione. Decyzja o opóźnieniu wdrażania umowy do 31 grudnia 2015 r. podjęta została przez przedstawicieli UE, Rosji i Ukrainy w połowie września. Podczas spotkania uzgodniono, iż Kijów korzystać będzie z jednostronnego zniesienia ceł przez Unię oraz kontynuowane będą trójstronne rozmowy na poziomie technicznym oraz ministerialnym dotyczące DCFTA między Unią, Rosją i Ukrainą do czasu jej wejścia w życie (1 styczeń 2016 r.). Przekonywano, iż takie działanie wspiera proces pokojowy, który toczy się na Ukrainie (Wdrażanie, 2014).

Zapowiedź prezydenta Putina z połowy października o wycofaniu wojsk rosyjskich z obszaru granicznego między Rosją i Ukrainą frakcja CDU/CSU przyjęła z zadowoleniem jako „ważny sygnał odprężenia”. Politycy chadecji podkreślali jednocześnie, że wycofanie wojsk to tylko pierwszy krok na drodze do pokojowego rozwiązania konfliktu we wschodniej Ukrainie. Według nich niezbędne były ,wiarygodne działania, przede wszystkim strony rosyjskiej. Musi ona rozwiać wszelkie wątpliwości dotyczące sprzedaży broni separatystom i wszystkich innych działań zagrażających stabilności Ukrainy. Kluczowym politycznym etapem byłoby przestrzeganie przez Rosję zasad OBWE” (Russischer, 2014). A. Merkel koncyliacyjnie oświadczyła, iż „globalne wyzwania można pokonać wyłącznie wspólnie". W tym duchu napominała Putina o jego odpowiedzialności za pokój we wschodniej Ukrainie przekonując, że „Moskwa musi wywrzeć decydujący wpływ na deeskalację". Kanclerz nie pozostawiła wątpliwości, że będzie domagała się od strony rosyjskiej realizacji porozumień. Po raz kolejny podkreślała, że sankcje wobec Rosji będą utrzymywane tak długo, jak długo nie będzie postępu w procesie pokojowym (Globale, 2014).

Po wyborach parlamentarnych na Ukrainie, w których wyraźnie zwyciężyły umiarkowane i proeuropejskie sily polityczne, frakcja CDU/CSU wezwała do szybkiego utworzenia rządu w Kijowie. A. Schockenhoff, skomentował, że wyborcy wyraźnie opowiedzieli się za Europą i tym samym powiedzieli ,nie” rosyjskim próbom destabilizacji i radykalnie prawicowym siłom. Natomiast Philipp Mißfelder podkreślał, iż przed Ukrainą wciąż stoją wielkie polityczne i gospodarcze wyzwania (Schnelle, 2014). Zupełnie inaczej chadecy zapatrywali się na wybory, które odbyły się we wschodniej Ukrainie na obszarach zajmowanych przez prorosyjskich separatystów. Według A. Schockenhoffa ich przeprowadzenie naruszyło umowy mińskie zawarte przez prezydenta Rosji, prezydenta Ukrainy i separatystów. Zastępca przewodniczącego frakcji parlamentarnej CDU/CSU ds. zagranicznych, obrony i Europy ostro oświadczyl, iż „takiej prowokacji Unia Europejska nie powinna po prostu przyjmować. Jej stwierdzenie, że głosowanie we wschodniej Ukrainie jest nielegalne i niezgodne z prawem, powinno 
mieć następstwa w działaniu. [...] Jednocześnie, w odpowiedzi na te prowokacje, UE musi podwoić wysiłki, wspierać naród ukraiński na drodze do europejskiego, demokratycznego i konstytucyjnego państwa" (Weitere, 2014).

Mimo wyraźnego sabotowania wysiłków na rzecz zawieszenia broni i jedności Ukrainy przez stronę rosyjską frakcja parlamentarna Lewica zaproponowała zniesienie sankcji gospodarczych, eliminację ograniczeń w podróżowaniu dla rosyjskich parlamentarzystów oraz postulowała większe zrozumienie między Rosją a Zachodem. Według Lewicy długie dyskusje na temat sankcji przeciwko Rosji nie rozwiązują politycznych problemów, ale je zaostrzają. Polityka sankcji tylko nakręca spiralę eskalacji, oznacza powrót do czasów zimnej wojny oraz szkodzi Unii i niemieckiej gospodarce (Antrag, 2014). Wniosek Lewicy wywołał burzliwą dyskusję w Bundestagu. Dr Hans-Peter Uhl zarzucił tej partii, że nie wspomniała o brutalności Rosji względem Ukrainy ani o próbach „zniszczenia i rozdarcia” tego kraju przez siły prorosyjskie. Przewodniczący grupy roboczej ds. polityki wewnętrznej frakcji CDU/CSU podkreślał, iż rząd niemiecki oraz Unia chcieliby jak najszybciej zrezygnować z sankcji, ale na chwilę obecną nie mogą, gdyż czują się zobowiązani do walki „o prawo każdego narodu, także ukraińskiego, do decydowania, czego chce" (Das ist, 2014). Manfred Grund dodawał, że chadecja i rząd niemiecki od początku kryzysu na Ukrainie wykluczali działania militarne. Oznaczało to, że środkiem, który pozostawał do dyspozycji były właśnie sankcje. Według członka komisji spraw zagranicznych frakcji CDU/CSU sq̨ one stosowane odpowiedzialnie i świadomie. Polityk podkreślał, iż zostaną zniesione, gdy Rosja przestanie destabilizować Ukrainę. Zdawał sobie jednakże sprawę, iż umowy zawarte w Mińsku już dawno zostały jednostronnie złamane przez uznanie przez Rosję „farsy wyborczej" w separatystycznych regionach na wschodzie Ukrainy. Wedhug Grunda rozejm we wschodniej Ukrainie jest nie tylko słaby, ale i systematycznie podważany poprzez dalsze wspieranie rebeliantów przez Rosje, która ,już narysowała mapę «Nowej Rosji», poprzez włączenie wschodniej i centralnej Ukrainy [...]" (Wir haben, 2014). Według A. Schockenhoffa wszystkie rozważania mające na celu złagodzenie sankcji wobec Rosji były całkowicie błędne. Postulował wręcz by sankcjami zostały objęte osoby, które były odpowiedzialne za przygotowanie i realizację nielegalnych wyborów we wschodniej Ukrainie (Weitere, 2014).

Nim przebrzmiały echa tej dyskusji F.-W. Steinmeier udał się z wizytą do Kijowa, a następnie do Moskwy. W stolicy Ukrainy minister spraw zagranicznych spotkał się z P. Poroszenką oraz A. Jaceniukiem. Omawiając sytuację na wschodzie kraju, niemiecki polityk przekonywał o konieczności realizowania porozumienia o zwieszeniu broni oraz zapewniał prezydenta i premiera o poparciu Unii dla wdrażania reform. Z kolei podczas rozmów z ministrem spraw zagranicznych Federacji Rosyjskiej Steinmeier nawoływał do przestrzegania protokołu mińskiego i deeskalacji konfliktu. Spotkanie nie przyniosło $\mathrm{w}$ tej kwestii przełomu, gdyż S. Ławrow po raz kolejny wysunął argument, że Unia usiłuje rozszerzyć swoją strefę wpływów kosztem rosyjskich interesów. Na wspólnej konferencji prasowej z ust Steinmeiera można było m.in. usłyszeć, iż nadszedł czas, by w stosunkach między oboma państwami wyjść poza myślenie tylko i wyłącznie o Ukrainie (Kalendarium 2, 2014).

Coraz bardziej sfrustrowana brakiem dyplomatycznych rozwiązań konfliktu A. Merkel nie zamierzała akceptować rosyjskiej polityki faktów dokonanych. W trakcie deba- 
ty w Bundestagu dotyczącej zbliżającego się szczytu państw G-20 przekonywała, iż nic nie usprawiedliwia i nie uzasadnia aneksji Krymu przez Rosję oraz bezpośredniego lub pośredniego udziału tego państwa w walkach w Doniecku i Ługańsku. Kanclerz podkreślała, iż Moskwa naruszyła integralność terytorialną Ukrainy, i to pomimo podjęcia się ochrony owej integralności wspólnie z Wielką Brytanią i Stanami Zjednoczonymi w Memorandum Budapesztańskim z 1994 r. Kanclerz po raz kolejny powtórzyła, iż nie można rozwiązać tego konfliktu militarnie. W związku z tym, iż sytuacja w Ługańsku i Doniecku wciąż daleka była od zawieszenia broni, popierana przez rząd i chadecję twardo stała na stanowisku, iż sankcje gospodarcze są i pozostaną nieuniknione (Deutschland ist, 2014). Przemawiając po szczycie agresję na Ukrainę określiła jako próbę odbudowy strefy wpływów i narzucenia Zachodowi reguł gry obowiązujących w czasach istnienia ZSRR. Wypowiedzi te miały za cel jednoznacznie zakomunikować Putinowi, że kanclerz i rząd niemiecki czekają na konkretne działania Kremla i nie dają się zwieść propagandowym działaniom i komunikatom strony rosyjskiej. Ostre słowa ze strony Merkel nie oznaczały jednakże zmiany kursu, który obrała wobec Rosji. Kanclerz nadal miała zamiar podejmować działania włączające to państwo do współpracy w kształtowaniu bezpieczeństwa międzynarodowego (Ciechanowicz, 2014).

$\mathrm{Na}$ początku grudnia w obwodach donieckim i ługańskim zorganizowano wybory do rad najwyższych, w których wygrali dotychczasowi przywódcy separatystów - Aleksander Zacharczenko i Igor Płotnicki. Wybory nie zostały uznane przez rząd w Kijowie, państwa zachodnie, ONZ, NATO, OBWE oraz Białoruś. Jedynie rosyjski MSZ wydał krótkie oświadczenie, w którym potwierdził ich ważność (Sus, 2014). Bezpośrednio przed grudniowym szczytem Rady Europejskiej kanclerz Merkel w przemówieniu w Bundestagu podkreślała, iż celem Unii jest suwerenna i integralna pod względem terytorialnym Ukraina oraz że Unia nie może pozwolić sobie na to, żeby Moskwa łamała zasady prawa, wzajemnego respektu i partnerstwa (Das Ergebnis, 2014).

Podczas spotkania w tzw. formacie normandzkim ministrów spraw zagranicznych Francji, Niemiec, Rosji i Ukrainy, które odbyło się 21 stycznia 2015 r. w Berlinie, Rosja i Ukraina zawarly porozumienie odnośnie wycofania ciężkiej broni ze strefy wzdhuż linii demarkacyjnej we wschodniej Ukrainie, której utworzenie uzgodniono we wrześniu. F.-W. Steinmeier skomentował, że osiągnięto ,widoczne postępy, które nie oznaczają jeszcze przełomu" (Grupa kontaktowa, 2015). Eskalacja walk w regionie Doniecka i Ługańska spowodowała, iż Rada przedłużyła do września 2015 r. sankcje indywidualne wobec 132 osób i 28 podmiotów za działania zagrażające lub podważające suwerenność i integralność terytorialną Ukrainy. Wkrótce potem jednomyślnie objęła sankcjami kolejnych separatystów na wschodzie Ukrainy i ich zwolenników w Rosji (Unijne, 2015). W związku z zaogniającą się sytuacją, A. Merkel postanowiła zrezygnować ze sprzeciwu wobec spotkania w Moskwie, jeszcze mocniej zaangażować się w prowadzenie negocjacji ze stroną rosyjską i doprowadzić do zawieszenia broni, od którego uzależniała prowadzenie dalszych rozmów politycznych i zniesienie sankcji gospodarczych wobec Rosji. 12 lutego zawarte zostało 2 porozumienie mińskie zakładające m.in. zawieszenie broni oraz wycofanie ciężkiego sprzętu z obszaru walk. Kanclerz nawoływała do przestrzegania umowy, określając takie działanie ,jedyną szansą na pokój”. Jako że apel nie przyniósł oczekiwanego skutku przed kolejnym szczytem 
Rady Europejskiej (19-20 marca) A. Merkel wezwała do powiązania istniejącego systemu sankcji z wykonaniem porozumień mińskich (Kalendarium 3, 2015). Jednoznaczne stanowisko Merkel było również odpowiedzią na krytyczne głosy odnośnie konfrontacyjnego kursu z Rosją płynące ze strony niemieckiej Lewicy i części posłów SPD oraz przedstawicieli świata biznesu (Sus, 2014). Rada przychyliła się do tego postulatu.

Przed IV szczytem Partnerstwa Wschodniego w Rydze (21-22 maj) kanclerz ponownie podkreślała, że zbliżenie z Unią nie jest skierowane przeciw Rosji i nie oznacza alternatywy z rodzaju ,albo Rosja albo Unia”. Dodała przy tym, że Partnerstwo Wschodnie nie jest pierwszym krokiem do członkostwa w Unii Europejskiej, lecz narzędziem modernizacji państw z nią współpracujących (Kalendarium 3, 2015). Podczas wizyty w Moskwie A. Merkel opowiedziała się za całościową implementacja porozumień mińskich. Zgadzając się z tym postulatem W. Putin przypomniał większość rosyjskich postulatów dotyczących uregulowania sytuacji na Ukrainie. Wezwał m.in. do ustanowienia bezpośrednich kontaktów pomiędzy Kijowem a separatystami z Doniecka i Ługańska, zakończenia „blokady ekonomicznej” Donbasu oraz wprowadzenia amnestii dla uczestników działań zbrojnych w tym rejonie, przeprowadzenia reformy konstytucyjnej i lokalnych wyborów oraz nadania separatystycznym regionom „specjalnego statusu”. Rozmowy nie przyniosły żadnego przełomu, gdyż rozbieżności stanowisk Merkel i Putina wobec kryzysu okazały się być zbyt duże (Strzelecki, 2015).

Zgodnie z czerwcową decyzją RE wprowadzone przeciwko Rosji sankcje gospodarcze mają pozostać w mocy do 2016 r. (Unijne, 2015).

Konflikt rosyjsko-ukraiński zmusił niemieckich polityków związanych z CDU i CSU do zrewidowania poglądów na temat rosyjskiej polityki zagranicznej oraz relacji niemiecko-rosyjskich. Zgadzają się oni, iż pogwałcenie przez Federację Rosyjską prawa międzynarodowego przez naruszenie suwerenności i integralności terytorialnej Ukrainy, nękanie chcących zbliżenia z Unią Europejską państw postsowieckich i destabilizacja całego porządku europejskiego wymagały odpowiedzi Zachodu. Nie ma jednakże pełnej zgody co do sposobu reakcji Niemiec na rosyjskie działania.

Wypowiedzi zdecydowanej większości polityków frakcji CDU/CSU oraz A. Merkel sugerowały, iż długotrwałe rozwiązanie kryzysu możliwe jest wyłącznie z zaangażowaniem Rosji. W tym duchu kanclerz zaproponowała utworzenie tzw. grupy kontaktowej, która miała umożliwić rosyjsko-ukraińskie rozmowy przy mediacji międzynarodowych partnerów. Niektórzy przedstawiciele chadecji otwarcie mówili o uwzględnieniu rosyjskiego stanowiska i interesów (P. Mißfelder, P. Gauweiler), byli jednak w zdecydowanej mniejszości. Czesść podkreślała, że zarówno politycznie, jak i gospodarczo Federacja Rosyjska ma o wiele więcej do stracenia niż Niemcy i Unia (W. Schäuble, K.-G. Wellmann). Próbowano rozwiać rosyjskie obawy przekonując, iż przystapienie Ukrainy do Partnerstwa Wschodniego nie jest skierowane przeciwko Rosji oraz wycofując się z zarysowywania perspektyw wstąpienia tego państwa do Unii (A. Schockenhoff, A. Merkel). Ponadto rząd federalny, przy poparciu chadeków, zaczął 
przywiązywać jeszcze większą wagę do takiej modyfikacji unijnej polityki sąsiedztwa, by integracja gospodarcza z UE nie wykluczała rozwijania współpracy państw Partnerstwa Wschodniego z Moskwa.

Przedstawiciele CDU i CSU nie byli jednomyślni odnośnie wprowadzania przez Unię Europejską sankcji gospodarczych względem Federacji Rosyjskiej. Kilkoro posłów opowiadało się przeciwko ich wdrożeniu (P. Gauweiler) lub za ich zaostrzeniem (A. Schockenhoff, G. Kirchbaum). Większość zgadzała się z poglądem A. Merkel, iż sankcje są środkiem ostatecznym, po który sięga się, gdy Rosja łamie prawo międzynarodowe i nie stosuje się do zawartych porozumień. Mimo eskalacji kryzysu przez stronę rosyjską i prorosyjskich separatystów wszyscy chadeccy posłowie wykluczali działania militarne oraz zgadzali się z koniecznością poszukiwania dyplomatycznego rozwiązania. Jednogłośnie popierali również stanowisko A. Merkel odnośnie udzielenia Ukrainie politycznego i finansowego wsparcia w kryzysie.

Politycy chadeccy nie sprzeciwiali się pełnieniu przez RFN tradycyjnej roli łącznika w utrzymywaniu dialogu między Moskwą i Brukselą, która wynikała zarówno z postrzegania pozycji państwa niemieckiego w polityce międzynarodowej, jak i chęci utrzymania dobrych relacji politycznych i gospodarczych z Rosją. Większość wyrażała również zrozumienie dla postawy państw członkowskich, które życzyły sobie, by Niemcy przyjęły na siebie rolę kreatora unijnej polityki wobec konfliktu rosyjsko-ukraińskiego. Frakcja CDU/CSU wyraziła gotowość do spełnienia oczekiwań dotyczących pokojowego rozwiązywania kryzysów i konfliktów przy pomocy środków dyplomatycznych i współpracy na rzecz rozwoju. Niektórzy politycy winą za „dyplomatyczną katastrofę", czyli fiasko rozmów między Brukselą, Kijowem i Moskwą, obarczali nie tylko Federację Rosyjską, ale również UE. W ocenie chadeków Unia nie doceniła geopolitycznej kwestii Ukrainy dla Rosji oraz podstawowych wewnętrznych konfliktów politycznych na Ukrainie, których nie można było usunąć poprzez podpisanie umowy stowarzyszeniowej (M. Stübgen).

Jako że A. Merkel, a z nią posłowie CDU i CSU, opowiadają się za środkami dyplomatycznymi i wykluczają działania militarne oraz kierują się przekonaniem, że Europa skazana jest na współpracę z Federacją Rosyjska, gdyż od tego zależy dobrobyt i bezpieczeństwo kontynentu, w najbliższym czasie nie należy oczekiwać radykalnej zmiany w polityce Niemiec oraz Unii Europejskiej wobec Rosji i konfliktu rosyjsko-ukraińskiego.

\section{Bibliografia}

Antrag der Abgeordneten Wolfgang Gehrcke, Klaus Ernst, Jan van Aken, Christine Buchholz, Dr. Diether Dehm, Annette Groth, Heike Hänsel, Inge Höger, Andrej Hunko, Katrin Kunert, Stefan Liebich, Niema Movassat, Dr. Alexander S. Neu, Alexander Ulrich und der Fraktion DIE LINKE. Einstieg in den Ausstieg - Sanktionen gegen Russland aufheben, Drucksache 18/3147, 12.11.2014, http://dipbt.bundestag.de/dip21/btd/18/031/1803147.pdf, 10.01.2015.

Ausschreitungen in der Ukraine, 19.02.2014, https://www.cducsu.de/presse/o-toene/ausschreitungen-der-ukraine, 10.01.2015.

Beschluss der Geschäftsführenden Vorstände vom 28. April 2014. Deutsche Außenpolitik als Beitrag zur Lösung von Krisen und Konflikten, 28.04.2014, https://www.cducsu.de/sites/default/files/ uploads/top2-aussenpolitik.pdf, 10.01.2015. 
Blyskawiczne tempo Rosjan. Putin anektowat Krym dwie doby po referendum, 18.03.2014, http://www.tvn24.pl/wiadomosci-ze-swiata,2/blyskawiczne-tempo-rosjan-putin-anektowalkrym-dwie-doby-po-referendum,408990.html, 10.01.2015.

CDU/CSU solidarisch mit der friedlichen Opposition in der Ukraine, 11.12.2013, https://www.cducsu.de/ presse/pressemitteilungen/cducsu-solidarisch-mit-der-friedlichen-opposition-der-ukraine. 10.01.2015.

Chance auf friedliche, demokratische und rechtsstaatliche Entwicklung in der Ukraine nutzen. Unterstützung für den neuen Regierungschef der Ukraine, 27.02.2014, https://www.cducsu.de/ presse/pressemitteilungen/chance-auf-friedliche-demokratische-und-rechtsstaatliche-entwicklung-der, 10.01.2015.

Ciechanowicz A., Rosja dzieli RFN. Analizy, 26.11.2014, http://www.osw.waw.pl/pl/publikacje/ analizy/2014-11-26/rosja-dzieli-rfn, 10.01.2015.

Council 1: Council of the European Union, Council conclusions on Ukraine, Foreign Affairs Council meeting, Brussels, 3 March 2014, http://www.consilium.europa.eu/uedocs/cms_data/docs/ pressdata/en/foraff/141291.pdf, 10.01.2015.

Council 2: Council of the European Union, Council conclusions on Ukraine, Foreign Affairs Council meeting, Brussels, 17 March 2014, http:/www.consilium.europa.eu/uedocs/cms_data/docs/ pressdata/EN/foraff/141601.pdf, 10.01.2015.

Das Ergebnis einer richtigen Politik. Rede zur Regierungserklärung durch Bundeskanzlerin Dr. Angela Merkel zum Europäischen Rat am 18./19. Dezember 2014 in Brüssel, 18.12.2014. https://www.cducsu.de/themen/aussen-europa-und-verteidigung/das-ergebnis-einer-richtigen-politik, 10.01.2015.

Das ist nichts anderes als Großmachtpolitik. Rede zu Einstieg in den Ausstieg - Sanktionen gegen Russland aufheben, 13.11.2014, https://www.cducsu.de/themen/aussen-europa-und-verteidigung/ das-ist-nichts-anderes-als-grossmachtpolitik, 10.01.2015.

Das Ziel ist der Verfassungsdialog. Rede zur Lage in der Ukraine, 20.02.2014, https://www.cducsu.de/ themen/aussen-europa-und-verteidigung/das-ziel-ist-der-verfassungsdialog, 10.01.2015.

„Der Kalte Krieg ist für alle vorbei”, 18.11.2013, https:/www.cducsu.de/themen/aussenpolitik/ der-kalte-krieg-ist-fuer-alle-vorbei, 10.01.2015.

Deutschland stellt sich seiner Verantwortung gegenüber der Ukraine. Bundesregierung sagt der: Ukraine Kreditbürgschaften in Höhe von 500 Millionen Euro zu, 26.08.2014. https://www.cducsu.de/themen/aussen-europa-und-verteidigung/deutschland-stellt-sichseiner-verantwortung-gegenueber-der-ukraine, 10.01.2015.

Deutschland ist Garant für Verlässlichkeit und Stabilität. Rede zum Einzelplan des Bundeskanzleramt (inkl. BKM), 26.11.2014, https://www.cducsu.de/themen/wirtschaft-und-energie-haushalt-und-finanzen/deutschland-ist-garant-fuer-verlaesslichkeit-und-stabilitaet, 10.01.2015.

Die NATO sichert Ukraine Unterstützung zu. Gipfelteilnehmer in Wales zeigen Geschlossenheit, 5.09.2014, https://www.cducsu.de/presse/pressemitteilungen/die-nato-sichert-ukraine-unterstuetzung-zu, 10.01.2015.

„Die territoriale Integrität der Ukraine steht nicht zur Disposition”. Kanzlerin gibt Regierungserklärung zur Krim-Krise - Militärische Reaktion ausgeschlossen, 13.03.2014, https://www.cducsu.de/themen/aussen-europa-und-verteidigung/die-territoriale-integritaetder-ukraine-steht-nicht-zur, 10.01.2015.

Dreiklang unseres Handelns als Bundesregierung: Gespräche, Hilfen und Sanktionen. Regierungserklärung zur Situation in der Ukraine, 13.03.2014, https://www.cducsu.de/themen/aussen-europa-und-verteidigung/dreiklang-unseres-handelns-als-bundesregierung-gespraeche, 10.01.2015. 
Es geht um Friede, Freiheit, Menschenwürde und Demokratie. Rede zur Lage in der Ukraine, 20.02.2014, https:/www.cducsu.de/themen/aussen-europa-und-verteidigung/es-geht-um-friede-freiheit-menschenwuerde-und-demokratie, 10.01.2015.

EU-Assoziierungsabkommen mit der Ukraine baldmöglichst unterzeichnen. CDU/CSU-Bundestagsfraktion begrüßßt Beschluss des Europäischen Rates, Ukraine finanziell zu unterstützen. 7.03.2014, https://www.cducsu.de/presse/pressemitteilungen/eu-assoziierungsabkommen-mit-der-ukraine-baldmoeglichst-unterzeichnen.

Fraktion begrüßt Ausweitung der EU-Sanktionen gegen Russland. Weitere Strafmaßnahmen angekündigt - Geschlossenes Vorgehen ist „,deutliches politisches Zeichen”, 25.07.2014, https://www.cducsu.de/themen/aussen-europa-und-verteidigung/fraktion-begruesst-ausweitung-der-eu-sanktionen-gegen-russland, 10.01.2015.

Freiheit, politische Stabilität, Rechtsstaatlichkeit, wirtschaftliche Stärke, Gerechtigkeit. Regierungserklärung, 29.01.2014, https://www.cducsu.de/themen/freiheit-politische-stabilitaet-rechtsstaatlichkeit-wirtschaftliche-staerke-gerechtigkeit.

Frieden, Freiheit und Wohlstand in der Welt festigen. Regierungserklärung der Bundeskanzlerin zum EU- und G7-Gipfel, 4.06.2014, https://www.cducsu.de/themen/aussen-europa-und-verteidigung/frieden-freiheit-und-wohlstand-der-welt-festigen, 10.01.2015.

Frieden, Sicherheit und die Stärke des Rechts in ganz Europa. Regierungserklärung der Bundeskanzlerin zum EU- und G7-Gipfel, 4.06.2014, https://www.cducsu.de/themen/aussen-europa-und-verteidigung/frieden-sicherheit-und-die-staerke-des-rechts-ganz-europa, 10.01.2015.

Friedliches und selbstbestimmtes Zusammenleben der Völker Rede zur Situation in der Ukraine, 13.03.2014, https://www.cducsu.de/themen/aussen-europa-und-verteidigung/friedliches-und-selbstbestimmtes-zusammenleben-der-voelker, 10.01.2015.

Gespräche über eine Lösung des Ukraine-Konflikts werden weiter fortgesetzt. Erstes Treffen der Präsidenten Russlands und der Ukraine seit Anfang Juni, 19.08.2014, https://www.cducsu.de/ themen/aussen-europa-und-verteidigung/gespraeche-ueber-eine-loesung-des-ukraine-konflikts-werden-weiter-fortgesetzt, 10.01.2015.

Gewalt ist kein Weg für die Ukraine. Konkrete Maßßnahmen gefordert, 19.02.2014, https://www.cducsu.de/ presse/pressemitteilungen/gewalt-ist-kein-weg-fuer-die-ukraine, 10.01.2015.

„Globale Herausforderungen bewältigen wir nur gemeinsam". Bundeskanzlerin Merkel gibt Ausblick auf EU- und ASEM-Gipfel, 16.10.2014, https://www.cducsu.de/themen/aussen-europa-und-verteidigung/globale-herausforderungen-bewaeltigen-wir-nur-gemeinsam, 10.01.2015.

„Gruppe der Sieben ist eine Wertegemeinschaft", 4.06.2014, https://www.cducsu.de/themen/ aussen-europa-und-verteidigung/gruppe-der-sieben-ist-eine-wertegemeinschaft, 10.01.2015.

Kalendarium 1: Kalendarium, „Biuletyn Niemiecki”, nr 45, 28.03.2014 r., http://fwpn.org.pl/assets/Publikacje/Biuletyn_Niemiecki/BIULETYN_NIEMIECKI_NR_45.pdf, 10.01.2015.

Kalendarium 2: Kalendarium, „Biuletyn Niemiecki”, nr 54 z 20.12.2014 r., http://fwpn.org.pl/assets/ Publikacje/Biuletyn_Niemiecki/2015/BIULETYN_NIEMIECKI_NR_54.pdf, 10.01.2015.

Kalendarium 3: Kalendarium, „Biuletyn Niemiecki” nr 57, 31.03 .2015 r., http://fwpn.org.pl/assets/ Publikacje/Biuletyn_Niemiecki/2015/BIULETYN_NIEMIECKI_NR_57.pdf, 10.05.2015.

Kriegerischer Akt Russlands. Verhöhnung aller diplomatischen Bemühungen, 29.08.2014, https://www.cducsu.de/presse/pressemitteilungen/kriegerischer-akt-russlands, 10.01.2015.

Merkel: „Die G8 gibt es nicht mehr”. Bundeskanzlerin gibt Regierungserklärung zum EU-GipfelRussland ist isoliert, 20.03.2014, https://www.cducsu.de/themen/aussen-europa-und-verteidigung/merkel-die-g8-gibt-es-nicht-mehr, 10.01.2015.

Moskau muss sich jetzt eindeutig von Separatisten distanzieren. Nach Ankündigung des Abspaltungsreferendums, 8.05.2014, https://www.cducsu.de/presse/pressemitteilungen/moskau-muss-sich-jetzt-eindeutig-von-separatisten-distanzieren, 10.01.2015. 
Nur das ukrainische Volk selbst kann aus dieser Krise herausfinden. Rede zur Lage in der Ukraine, 20.02.2014, https://www.cducsu.de/themen/aussen-europa-und-verteidigung/nur-das-ukrainische-volk-selbst-kann-aus-dieser-krise, 10.01.2015.

Politische Lösung für die Ukraine. Bericht des Fraktionsvorsitzenden, 11.03.2014, https://www.cducsu.de/ themen/aussen-europa-und-verteidigung/politische-loesung-fuer-die-ukraine, 10.01.2015.

Politischen Reformprozess unterstützen. Rede zur aktuellen Situation in der Ukraine, 31.01.2014, https://www.cducsu.de/themen/aussen-europa-und-verteidigung/politischen-reformprozessunterstuetzen, 10.01.2015.

Poroschenko ist der legitime Präsident der Ukraine. Russland muss Ergebnis anerkenen, 26.05.2014, https://www.cducsu.de/presse/pressemitteilungen/poroschenko-ist-der-legitime-praesident-der-ukraine, 10.01.2015.

Rada Europejska, Oświadczenie szefów państw lub rzadów w sprawie Ukrainy, Bruksela, 6 marca 2014 r, Bruksela, 6 marca 2014 r. (06.03) (OR. en), http:/www.consilium.europa.eu/uedocs/ cms_data/docs/pressdata/PL/ec/141391.pdf, 10.01.2015.

Rada Europejska, Specjalne posiedzenie Rady Europejskiej (16 lipca 2014 r.), konkluzje, Bruksela, 16 lipca $2014 \mathrm{r}$ (OR. en), EUCO 147/14, CO EUR 9, CONCL 3, http://www.consilium.europa.eu/pl/meetings/european-council/2014/07/16/, 10.01.2015.

Realistische und zugleich werteorientierte Außenpolitik. Rede zur Haushaltsberatung: Auswärtiges Amt, 9.04.2014, https://www.cducsu.de/themen/aussen-europa-und-verteidigung/realistische-und-zugleich-werteorientierte-aussenpolitik, 10.01.2015.

Rede von Außenminister Frank-Walter Steinmeier bei der Amtsübergabe im Auswärtigen Amt am 17. Dezember 2013, 17.12.2013, http://www.auswaertiges-amt.de/DE/Infoservice/Presse/ Reden/2013/131217-BM_Antrittsrede.html, 10.01.2015.

Rede von Bundeskanzlerin Angela Merkel anlässlich der 51. Münchner Sicherheitskonferenz, München, 7.02.2015, http://www.bundesregierung.de/Content/DE/Rede/2015/02/2015-02-07-merkel-sicherheitskonferenz.html, 10.05.2015.

Rede von Bundeskanzlerin Dr Angela Merkel zum Haushaltsgesetz 2014 vor dem Deutschen Bundestag am 9. April 2014 in Berlin, 9.04.2014, http://www.bundesregierung.de/Content/DE/Bulletin/2014/04/41-1-bk-bt.html, 10.01.2015.

Referendum im Osten hat keinerlei politische Relevanz. Schockenhoff betonte die Bedeutung einer geschlossenen Haltung der EU, 12.05.2014, https://www.cducsu.de/themen/referendum-im-osten-hat-keinerlei-politische-relevanz, 10.01.2015.

Regierungserklärung von Bundeskanzlerin Merkel, 13.03.2014, http://www.bundesregierung.de/ Content/DE/Regierungserklaerung/2014/2014-03-13-bt-merkel.html, 10.01.2015.

Regierung und Opposition der Ukraine müssen zum Dialog zurückkehren, 22.01.2014, https://www.cducsu.de/presse/pressemitteilungen/regierung-und-opposition-der-ukrainemuessen-zum-dialog-zurueckkehren, 10.01.2015.

Russischer Truppenabzug ist Signal der Entspannung. ASEM-Gipfel in Mailand für eine Lösung im Gasstreit nutzen, 13.10.2014, https://www.cducsu.de/presse/pressemitteilungen/russischer-truppenabzug-ist-signal-der-entspannung.

Russland bestimmt die Agenda und setzt die Fakten. Rede zur Regierungserklärung zum Europäischen Rat, 20.03.2014, https://www.cducsu.de/themen/aussen-europa-und-verteidigung/ russland-bestimmt-die-agenda-und-setzt-die-fakten, 10.01.2015.

Russland destabilisiert die Ukraine weiter Referendum im Osten hat keinerlei politische Relevanz. 12.05.2014, https://www.cducsu.de/presse/pressemitteilungen/russland-destabilisiert-die-ukraine-weiter, 10.01.2015. 
Russland muss den europäischen Weg der Ukraine anerkennen. Rede zur Situation in der Ukraine, 13.03.2014, https://www.cducsu.de/themen/aussen-europa-und-verteidigung/russland-muss-den-europaeischen-weg-der-ukraine-anerkennen, 10.01.2015.

Russlands Vorgehen ist ungeheuerlich. Interview in der Passauer Neuen Presse, 3.05.2014. https://www.cducsu.de/presse/texte-und-interviews/russlands-vorgehen-ist-ungeheuerlich, 10.01.2015.

"Russland wurde ausgeladen, und das ist genau das richtige Zeichen". Regierungserklärung der Bundeskanzlerin zum EU- und G7-Gipfel, 4.06.2014, https://www.cducsu.de/themen/aussen-europa-und-verteidigung/russland-wurde-ausgeladen-und-das-ist-genau-das-richtige-zeichen, 10.01.2015.

Strzelecki J., Kreml kontynuuje presjęna Niemcy w sprawie Ukrainy, 13.05.2015, http://www.osw.waw.pl/ pl/publikacje/analizy/2015-05-13/kreml-kontynuuje-presje-na-niemcy-w-sprawie-ukrainy, 10.06.2015.

Sanktion zwingend erforderlich. Gewaltsame Auseinandersetzungen sofort beenden, 19.02.2014, https://www.cducsu.de/presse/pressemitteilungen/sanktion-zwingend-erforderlich, 10.01.2015.

Schnelle Regierungsbildung in der Ukraine gefordert. CDU/CSU-Bundestagsfraktion begrüßt Wahlsieg der prowestlichen Kräfte, 27.10.2014, https:/www.cducsu.de/themen/aussen-europa-und-verteidigung/schnelle-regierungsbildung-der-ukraine-gefordert, 10.01.2015.

Sorge um die Ukraine. Aktuelle Stunde im Bundestag - Politik setzt weiter auf Diplomatie - Härtere Sanktionen nicht ausgeschlossen, 7.05.2014, https://www.cducsu.de/themen/aussen-europa-und-verteidigung/sorge-um-die-ukraine, 10.01.2015.

Strategisches Umfeld Europas befindet sich in einem tiefgrelfenden Wandel. Rede zur Regierungserklärung zum Europäischen Rat, 18.12.2013, https:/www.cducsu.de/themen/aussen-europaund-verteidigung/strategisches-umfeld-europas-befindet-sich-einem, 10.01.2015.

Sus M., Niemcy i Polska wobec konfliktu ukraińsko-rosyjskiego w drugiej polowie 2014 r, „Biuletyn Niemiecki", nr 54, 20.12.2014 r., http://fwpn.org.pl/assets/Publikacje/Biuletyn_Niemiecki/2015/BIULETYN_NIEMIECKI_NR_54.pdf, 10.01.2015.

Uklad o stowarzyszeniu między Uniq Europejska i jej państwami czlonkowskimi, z jednej strony, a Ukraina, z drugiej strony, „Dziennik Urzędowy Unii Europejskiej” L 161/3 z 29.05.2014. http://eur-lex.europa.eu/legal-content/PL/TXT/?uri=uriserv:OJ.L_.2014.161.01.0003.01.POL, 10.01.2015.

Ukraine: Stunde der Diplomatie noch nicht vorbei. Interview im Deutschlandfunk, 3.03.2014, https://www.cducsu.de/presse/texte-und-interviews/ukraine-stunde-der-diplomatie-noch-nicht-vorbei, 10.01.2015.

Unijne sankcje w odpowiedzi na kryzys na Ukrainie, http://www.consilium.europa.eu/pl/policies/ sanctions/ukraine-crisis/, 10.06.2015.

Weiterhin offen fur Partnerschaft mit der Ukraine, 29.11.2013, https://www.cducsu.de/themen/ europaeische-union/weiterhin-offen-fuer-partnerschaft-mit-der-ukraine, 10.01.2015.

Weg zur Demokratie in der Ukraine stabilisieren. Entscheidung für Europa und die europäischen Werte, 24.02.2014, https://www.cducsu.de/presse/pressemitteilungen/weg-zur-demokratie-der-ukraine-stabilisieren, 10.01.2015.

Weitere Sanktionen gegen Russland in Erwägung ziehen. Wahlen in der Ostukraine sind gravierender Verstoß gegen die Minsker Vereinbarungen, 3.11.2014, https://www.cducsu.de/presse/ pressemitteilungen/weitere-sanktionen-gegen-russland-erwaegung-ziehen, 10.01.2015.

Wir haben militärische Maßnahmen ausgeschlossen. Rede zum Einstieg in den Ausstieg - Sanktionen gegen Russland aufheben, 13.11.2014, https://www.cducsu.de/themen/aussen-europa-und-verteidigung/wir-haben-militaerische-massnahmen-ausgeschlossen, 10.01.2015. 
Wir wollen, dass Moskau politisch und ökonomisch ein starker Partner ist. Rede zur Situation in der Ukraine, 13.03.2014, https:/www.cducsu.de/themen/aussen-europa-und-verteidigung/ wir-wollen-dass-moskau-politisch-und-oekonomisch-ein-starker, 10.01.2015.

Grupa kontaktowa w sprawie Ukrainy spotka sie jutro w Mińsku, 29.01.2015, „Rzeczpospolita”, http://www.rp.pl/artykul/1175482.html, 10.05.2015.

Linke: Merkel soll nach Moskau fahren, 13.03.2014, „Neues Deutschland. Sozialistische Tageszeitung", http://www.neues-deutschland.de/artikel/926826.linke-merkel-soll-nach-moskau-fahren.html, 10.01.2015.

Russland hat uns einen Systemkonflikt aufgezwungen. Interview mit ZEIT ONLINE, 4.09.2014, „Zeit.online”, https://www.cducsu.de/presse/texte-und-interviews/russland-hat-uns-einen-systemkonflikt-aufgezwungen, 10.01.2015.

Ukraina. Wtadze Krymu przejmuja kontrole nad silami bezpieczeństwa, 1.03.2014, „Gazeta Wyborcza", http://wyborcza.pl/1,91446,15546871,Ukraina_Wladze_Krymu przejmuja kontrole_nad_silami.html, 10.01.2015.

Wdrażanie umowy o wolnym handlu UE-Ukraina odlożone do końca 2015 r., 12.09.2014, „PAP”, http:/www.pap.pl/palio/html.run?_Instance $=$ cms_www.pap.pl\&_PageID=1\&s=infopakiet\&dz= swiat\&idNewsComp $=175799 \&$ filename $=\&$ \&idnews $=179110 \&$ data $=\&$ status $=$ biezace $\&$ Check Sum $=965483635,10.01 .2015$.

\section{Streszczenie}

Niniejszy artykuł ma na celu prześledzenie stanowisk polityków niemieckiej chadecji wobec konfliktu rosyjsko-ukraińskiego oraz wpływu, jaki wywarli na działania Unii Europejskiej i Federacji Rosyjskiej. Przedstawia szeroki wachlarz opinii i komentarzy polityków chadeckich odnośnie polityeznego i gospodarczego zbliżenia Ukrainy z Unią oraz kryzysu na Ukrainie w okresie od listopada 2014 r. do czerwea 2015 r.

Slowa kluczowe: CDU/CSU, Ukraina, Federacja Rosyjska, Unia Europejska, konflikt

\section{German Christian-Democrats towards the Russian-Ukrainian conflict}

\section{Summary}

This paper presents the positions of German Christian Democrat politicians towards the Russian-Ukrainian conflict and the impact they exert on the activities of the European Union and the Russian Federation. It presents a wide range of opinions and comments of Christian Democrat politicians regarding the political and economic rapprochement of Ukraine with the EU and the crisis in Ukraine between November 2014 and June 2015.

Key words: CDU/CSU, Ukraine, Russian Federation, European Union, conflict 
